mine all of them or all of the residues within an individual antigenic site on a protein that are involved in binding an anti-protein antibody. Ultimate resolution will rely on more refined methods such as $\mathrm{X}$-ray crystallographic studies of antigenantibody complexes, as reported recently ${ }^{9}$. Further data are required to determine whether the correlation observed between mobility and antigenic sites in proteins $\mathrm{s}^{1,5,6}$, while significant, is also of immunological importance.

\section{RONALD JEMMERSON} YVONNE PATERSON

Department of Immunology,

Scripps Clinic and Research Foundation, 10666 North Torrey Pines Road, La Jolla, California 92037, USA

1. Westhof, E. et al. Nature 311, 123-126 (1984).

2. Benjamin, D. C et al. A. Rev. Immun 2, 67-101 (1984)

3. Crumpton, $M$. J in The Antigens (ed Sela, M.) 133-158 (Academic, New York, 1974).

4. Reichlin, M. Adv. Immun. 20,70-123 (1975)

5. Tainer, J. A., Getzoff, E. D., Paterson, Y., Otson, A. \& Lerner, R. A. A. Rev. immun 3, 501-535 (1985).

6. Moore, G. R. \& Williams, R. J. P. Eur. J. Biochem. 103, 543-550 (1980).

7. Bumet, F. M. Aust, J. Sci. 20, 67-69 (1975).

8. Jemmerson, R. \& Margoliash, E. Nature 282, 468-471 (1979).

9. Amit, A. G., Mariuzza, R. A., Phillips, S. E. V. \& Poljak, R. J. Nature 313, 156-158 (1985)

VAN RegenMortel and AltschuH REPLY-Jemmerson and Paterson imply that Westhof et al. ${ }^{1}$ have attempted to link the total antigenicity of proteins with regions of local mobility, and they suggest that such an attempt is bound to fail because anti-protein antibodies that bind peptides may not represent all of the antibodies present in the antisera. We wish to point out that there is no mention of total antigenicity in our paper and that, on the contrary, we stated clearly that "segmental flexibility in proteins emphasizes only one type of antigenic determinant", namely the type of continuous epitope that can be mimicked with short peptides. We also suggested that continuous epitopes are probably less numerous than the discontinuous epitopes revealed in the studies with monoclonal antibodies.

We agree that our study using short peptides was biased towards the detection of flexible epitopes. However, any experimental study of protein antigenicity will necessarily suffer from one operational bias or another. The monoclonal antibodies used in X-ray crystallographic studies of antigen-antibody complexes are selected for high binding affinity and are not representative of all the antibodies produced during the immune response; they will, therefore, present a biased view compared with the interactions that occur with low-affinity antibodies. A study of the antigenicity of related mammalian proteins that are subject to immunological tolerance can also be said to be biased compared with the study of antigens such as plant viruses, which are free from such restrictions. Each experimental approach used in the study of protein antigenicity will emphasize a particular aspect of the many types of interaction that constitute immunological recognition.

In view of our ignorance regarding the total antibody repertoires relevant for different protein antigens, it seems to us pointless to argue about the relative importance of these different experimental approaches. However, present interest in mimicking protein epitopes by means of short synthetic peptides underlines the immunological relevance of any observations that link mobility to the location of continuous epitopes in proteins.

\section{H. V. VAN REGENMORTEL D. AltsChuH}

Institut de Biologie Moléculaire et Cellulaire,

CNRS 67084 Strasbourg Cedex, France

1. Westhof, E. et al. Nature 311, 123-126 (1984).

TAINER ET AL. REPLY-Jemmerson and Paterson suggest a correlation between evolutionary variability and antigenicity, while noting that such variable regions are likely to be subject to fewer structural constraints. Their point is well taken for the generalization of the relationship between local mobility and antigenicity of protein sites, as identified by Westhof et al. for $\mathrm{TMV}^{1}$ and ourselves for myohaemeryth$\mathrm{rin}^{2}$, to other proteins that are affected by tolerance. The influence of tolerance is undoubtedly crucial in the majority of protein systems studied by immunologists. Currently, there appear to be a number of related structural parameters that bias antigenicity including sequence variability, hydrophilicity, solvent-accessibility, shape, and local mobility ${ }^{3,4}$, but it is difficult to determine which is the primary underlying correlate. The protein myohaemerythrin is a good model for antigenicity studies because it is not subject to tolerance, and it is unique in having highly accurate temperature factors corrected for the effects of crystal contacts ${ }^{5}$. We designed an experiment to address the specific question of why anti-peptide antibodies can recognize the native protein, and found a better relationship for local mobility than for these other parameters.

For anti-peptide antibodies, the parameters of hydrophilicity, shape and variability cannot explain what we term the order/disorder paradox, that is, how can an antibody raised against a presumably disordered peptide recognize the native, highly ordered protein? The results of our experiment help to resolve this paradox by suggesting that the antigenic sites of proteins should not be viewed as static, fixed conformations. Evidence from NMR and hydrogen/deuterium exchange rates also blurs the order/disorder distinction by revealing the differential mobility of protein sites ${ }^{3}$. The role of flexibility ${ }^{1,2,6}$ in facilitating the interaction of antigen with antibody adds the dimension of time to understanding the thermodynamics of antigen-antibody union. The correlation of flexibility with sequence variability, hydrophilicity, solvent-accessibility, and shape could account for the correlation of these related parameters with antigenicity, while simultaneously explaining the success of anti-peptide antibodies in recog. nizing the parent protein. Finally, the knowledge that mobility is an intrinsic molecular parameter affecting antigenantibody union has implications for any model of antigenic recognition in that it implies a multiple-step process rather than a single collision resulting in simple lockand-key complementarity.
JOHN A. TAINER
ELIZABETH D. GeTZOFF
HANNAH ALEXANDER
RICHARD A. HOUGHTEN
ARTHUR J. OLSON
RICHARD A. LERNER

Department of Molecular Biology, Research Institute of Scripps Clinic, 10666 North Torrey Pines Road, La Jolla, California 92037, USA

1. Westhof, E. et al. Nature 311, 123-126 (1984)

2. Tainer, J. A. et al. Nature 312, 127-134 (1984).

3. Williams, R. J. P. \& Moore, G. R. Trends biochem. Sci 10 96-97 (1985)

4. Tainer, J. A., Getzoff, E. D., Paterson, Y., Olson, A. J. \& Lerner, R. A. A. Rev. Immun, 3, 501-535 (1985).

5. Sherifl, S., Hendrickson, W. A., Stenkamp, R. E., Seiker, L. C. \& Jensen, L. H. Proc. natn. Acad. Sci. U.S.A. 82, 1104-1107 (1985)

6. Moore, G. R. \& Williams, R. J. P. Eur. J. Biochem. 103 , $543-550(1980)$

\section{Matters Arising}

Matters Arising is meant as a vehicle for comment and discussion about papers that appear in Nature. The originator of a Mátters Arising contribution should initially send his manuscript to the author of the original paper and both parties should, wherever possible, agree on what is to be submitted. Neither contribution nor reply (if one is necessary) should be longer than 500 words and the briefest of replies, to the effect that a point is taken, should be considered.

\section{Electronic reprints}

\section{Articles from Nature can be ordered using}

DIALOG/Dialorder, OnTyme, ITT

Dialcom, OCLC ILL Subsystem

and other systems. Write for

details, specifying the system you are interested in, to:

\section{UMI Article Clearinghouse, University Microfilms International, 300 North Zeeb Road, Box 91 , Ann Arbor, MI 48106, USA}

